\title{
非等温環境でのチアミン硝化物の安定性に及ぼす熱伝導と包装容器の影響
}

\author{
中村 亨, ${ }^{*}, a, b$ 山地貴 之, ${ }^{b}$ 高山幸三 ${ }^{a}$
}

\section{Effect of Heat Transfer in the Packages on the Stability of Thiamine Nitrate under Uncontrolled Temperature Conditions}

\author{
Toru Nakamura, ${ }^{*, a, b}$ Takayuki Yamaji, ${ }^{b}$ and Kozo Takayama ${ }^{a}$ \\ ${ }^{a}$ Department of Pharmaceutics, Hoshi University; 2-4-41 Ebara, Shinagawa-ku, Tokyo 142-8501, Japan: \\ and ${ }^{b}$ Oral Liquid Formulation, $R \& D$ Laboratories, Self Medication Business, Taisho Pharmaceutical \\ Company, Ltd.; 1-403 Yoshino-cho, Kita-ku, Saitama 331-9530, Japan.
}

(Received July 2, 2013; Accepted September 4, 2013)

\begin{abstract}
To accurately predict the stability of thiamine nitrate as a model drug in pharmaceutical products under uncontrolled temperature conditions, the average reaction rate constant was determined, taking into account the heat transfer from the atmosphere to the product. The stability tests of thiamine nitrate in the three packages with different heat transfers were performed under non-isothermal conditions. The stability data observed were compared with the predictions based on a newly developed method, showing that the stability was well predicted by the method involving the heat transfer. By contrast, there were some deviations observed from the predicted data, without considering heat transfer in the packages with low heat transfer. The above-mentioned result clearly shows that heat transfer should be considered to ensure accurate prediction of the stability of commercial pharmaceutical products under non-isothermal atmospheres.
\end{abstract}

Key words — - stability; thiamine nitrate; temperature; diffusion; simulation; kinetics

緒言

われわれの生活している現実の環境は温度が一定 ではないので，医薬品は一定の温度にコントロール された環境に常に保存されるとは限らない。特に, 救急医療, 旅行, 平和維持活動, 発展途上国援助及 び災害救助活動においては，医薬品は過酷でかつ非 等温の環境に曝される場合があるとの報告が多数な されている. ${ }^{1-6)}$ また，Küpper らは，救急医療に使 用される多くの薬及び剤形に関する情報を要約して おり，このような過酷な環境に曝された後の医薬品 は，少なくとも年に 1 度は交換することを推奨して

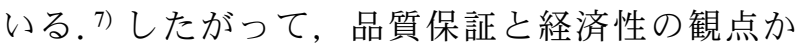
ら，極端な非等温の環境の中で使用される医薬品の 安定性を予測する方法は医療関係者にとって重要で あると考えられる。

非等温の環境に保存された医薬品の安定性につい

The authors declare no conflict of interest.

$a$ 星薬科大学薬学部薬剤学教室, $b$ 大正製薬株式会社セ ルフメディケーション開発研究所内服液剤開発研究室

*e-mail: too-nakamura@so.taisho.co.jp
ては，「平均キネティック温度」が Haynes ${ }^{8)}$ によっ て報告されて以来，このパラメータが広く使われて きている. ${ }^{9-12)}$ 平均キネティック温度とは，原薬又 は製剤が，ある一定の期間を通じて非等温環境下で 影響を受けた場合と同じ変化を与え得る一定温度の ことである。その他, Carstensen, ${ }^{13)}$ Okusa, ${ }^{14,15)}$ Scher, ${ }^{16)}$ 及び Terao ${ }^{17)}$ からの報告があるが，これら の研究では, 医薬品が保存される環境温度と製品温 度の差は考慮されておらず製品温度と環境温度は同 じとみなしている.

われわれはこれまでに，環境温度と製品温度の差 による熱伝導を考慮して製品温度を算出し，この製 品温度から活性成分の平均反応速度を予測する方法 を新たに考案し, 熱伝導性の異なる 3 種の包装容器 に入れた製品の温度の予測值と実測值がよく一致す ることを見い出した. ${ }^{18)}$ さらに製品の熱伝導率と熱 容量に関連するパラメータである「見かけの熱拡散 率 $\left(\kappa_{\mathrm{a}}\right) 」$ を指標とし，この值が中間領域に入る製 品を非等温環境に保存する場合には，活性成分の安 定性を推定する上で熱伝導を考慮する必要があるこ とを報告している. ${ }^{18)}$ 今回この方法により推定した 
製品中の活性成分の残存量が実測值をどの程度反映 するかを検証するため，チアミンを活性成分とした モデル処方を熱伝導性の異なる 3 種の包装容器に入 れ，人工的に作り出した非等温環境に保存し，経時 的に活性成分の残存量を調べたので報告する.

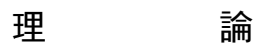

検討対象とする部分を対象製品の特定位置に限定 すれば，その部分の熱伝導による温度変化は時間に のみ依存するとみなせるので，熱伝導に関するフー リエの法則は常微分方程式となり Eq. (1) で表すこ とができる. ${ }^{18)}$

$$
\begin{gathered}
q=-\lambda \frac{d T}{d X} \longrightarrow V \frac{C v}{S} \frac{d T}{d t}=\frac{\lambda}{L}(T a-T p) \\
\longrightarrow \frac{d T}{d t}=\kappa_{\mathrm{a}}(T a-T p)
\end{gathered}
$$

ここで， $q$ は熱流束， $X$ は熱伝導距離， $\lambda$ は熱伝 導率， $L$ は熱拡散層の厚さ， $S$ は伝熱有効面積， $C v$ は単位体積あたりの熱容量， $V$ は対象物（製品）の 体積， $T a$ は環境温度（気温）, $T p$ は対象物（製品） の温度， $\kappa_{\mathrm{a}}$ は見かけの熱拡散率 $\left(\kappa_{\mathrm{a}}=S \lambda / V L C v\right)$ をそれぞれ示す。また，分割された時間内では気温 が一定とみなせるように微小時間 $\Delta t_{i}\left(\Delta t_{i}=t_{i+1}-t_{i}\right)$ に製品の保存期間を分割すると，分割した特定時刻 $\left(t_{i+1}\right)$ の製品温度 $\left(T_{P i+1}\right)$ は，その直前の期間 $\left(\Delta t_{i}\right)$ に，気温 $\left(T_{a i}\right)$ と製品温度 $\left(T_{P i}\right)$ の温度差 を駆動力として，Eq. (1) に従って $T_{P i}$ から変化す ると考えられる.ここで $\Delta t_{i}$ では気温 $\left(T_{a i}\right)$ は一定 とみなせるので，これらの条件を入れて Eq. (1)の 微分方程式を解き，これを整理すると Eq. (2)が得 られる。

$$
T_{P i+1}=T_{a i}-\left(T_{a i}-T_{P i}\right) \exp \left[-\kappa_{\mathrm{a}}\left(t_{i+1}-t_{i}\right)\right]
$$

特定時刻の製品の反応速度定数 $\left(k_{i}\right)$ はその時刻 の温度 $\left(T_{P i}\right)$ を基にアレニウスの式 Eq. (3)より算 出される，ここで，A は頻度因子， $E$ は活性化エネ ルギー， $R$ は気体定数をそれぞれ示し，アレニウス プロットが直線にならない場合は修正アレニウス式 $\left(k_{i}=A\left(T_{p i}\right)^{\mathrm{n}} \exp \left(-E / R T_{p i}\right)\right){ }^{19)}$ が使用できる.

$$
k_{i}=A \exp \left(-\frac{E}{R T_{P i}}\right)
$$

以上の仮定に基づいて，当該保存期間の平均反応 速度定数 $\left(k_{r e}\right)$ は, 当該時刻の反応速度定数 $\left(k_{i}\right)$ に分割した微小時間の重み（ $\left.\Delta t_{i}\right)$ をかけて平均化
し，Eq. (4)により算出することができる.ここで, $t_{s p}$ は保存期間を示す。なお，平均反応速度定数の 算出については，筆者らの前報18)にて詳述している.

$$
k_{r e}=\frac{\sum\left(k_{i} \Delta t_{i}\right)}{\sum\left(\Delta t_{i}\right)}=\frac{\sum\left(k_{i} \Delta t_{i}\right)}{t_{s p}}
$$

一方，熱伝導を考慮しない（製品温度はすべての 時点で気温と一致する，見かけの熱拡散率が無限大 の場合に相当）平均反応速度定数 $k_{i n}$ は $T_{P i}=T_{a i}$ と して Eq. (3)と (4)より算出することができる.さ らに, この平均反応速度定数を擬一次反応速度式に 当てはめることにより，所定時間の活性成分の残存 率 $X$ は Eq. (5)により算出される。ここで， $k$ は保 存期間中の平均反応速度定数 $\left(k_{r e}\right.$ 又は $\left.k_{i n}\right)$ を示す.

また，モデル非等温環境の気温と見かけの熱拡散率 から，Eq. (2)を用いて製品温度を推定することが 可能である.

$$
X=\exp \left(-k t_{s p}\right)
$$

\section{方法}

1. 試薬 活性成分としてチアミン硝化物（日 本薬局方）を用いた，それ以外の試薬は，クエン酸 水和物 (日本薬局方), $1 \mathrm{~mol} / \mathrm{L}$ 水酸化ナトリウム 溶液（容量分析用，和光純薬），ジフェンヒドラミ ン塩酸塩 (日本薬局方), リン酸 (特級, 和光純薬), リン酸二ナトリウム（特級，和光純薬）, ドデシル 硫酸ナトリウム（sodium dodecyl sulfate; SDS，一 級, 和光純薬), メ夕ノール (HPLC 用, 和光純薬) を用いた。

2. モデル処方と包装容器所定量のチアミン 硝化物（VB1 と略）とクエン酸水和物を精製水に 溶解し，これに $1 \mathrm{~mol} / \mathrm{L}$ 水酸化ナトリウム溶液を 加えて pH 3.4 に調整し，この組成の溶液をガラス 瓶に充填した。これらのガラス瓶をさらに前報18)で 用いた 2 次容器（紙箱又は発泡スチロールの箱）に 入れ，見かけの熱拡散率と非等温環境での活性成分 の安定性を評価した。モデル処方の組成を Table 1 に示す.

試料 1 (Product 1)：ガラス瓶（直径 $46 \mathrm{~mm}$, 高 さ $122 \mathrm{~mm})$

試料 2（Product 2)：紙箱（縦 $230 \mathrm{~mm}$, 横 94 $\mathrm{mm}$, 高さ $122 \mathrm{~mm})$ に試料 1 を 10 本入れたもの

試料 3 (Product 3)：発泡スチロール箱（縦 230 $\mathrm{mm}$ ，横 $244 \mathrm{~mm}$ ，高さ $269 \mathrm{~mm}$ ）に試料 1 を 3 本 


\section{入れたもの}

\section{3. 経時変化試験 活性化エネルギーの算出の} ためにガラス瓶に充填した試料を等温環境 $(85,65$,

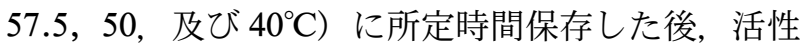
成分の定量を行つた。 また，非等温環境に保存され た試料に含まれる活性成分の安定性を評価するため,

Fig. 1 に示すモデル非等温環境の繰り返し（恒温恒 湿槽：CH33-13P；ナガノサイエンス）に試料 1-3 を保存し，温度計（サーモレコーダーRT-13；エ スペックミック株) を用いて試料温度の時間変化を 測定するとともに，所定時間保存後の試料中の活性 成分の定量を行つた。 なお, 経時変化試験は, 試料 を水浴で所定の温度まで加温した後直ちに開始し， 試験終了後は直ちに冷却した。

4. 活性成分の定量方法試料 $2.5 \mathrm{~mL}$ を 20 $\mathrm{mL}$ メスフラスコに採取し, これに内部標準溶液 (ジフェンヒドラミン塩酸塩 $500 \mathrm{mg}$ を希釈液（水/ メタノール/リン酸混合液 $(800: 200: 1)) 200 \mathrm{~mL}$ に溶解したもの） $2 \mathrm{~mL}$ を加え，希釈液で正確に 20 $\mathrm{mL}$ としたものを HPLC（HPLC システム：島津 LC-2010CHT, 検出 : $260 \mathrm{~nm}$, 分離カラム : TSKgel

Table 1. Composition of the Model Formulation

\begin{tabular}{ll}
\hline \multicolumn{1}{c}{ Component } & \multicolumn{1}{c}{ Content $(\mathrm{mg})$} \\
\hline Thiamine nitrate $(\mathrm{VB} 1)$ & 4.37 \\
Citric acid monohydrate & 483 \\
$\begin{array}{l}1 \mathrm{~mol} / \mathrm{L} \text { Sodium hydroxide } \\
\text { aqueous solution }\end{array}$ & adequate amount \\
Purified water & total $50 \mathrm{~mL}$ \\
\hline
\end{tabular}

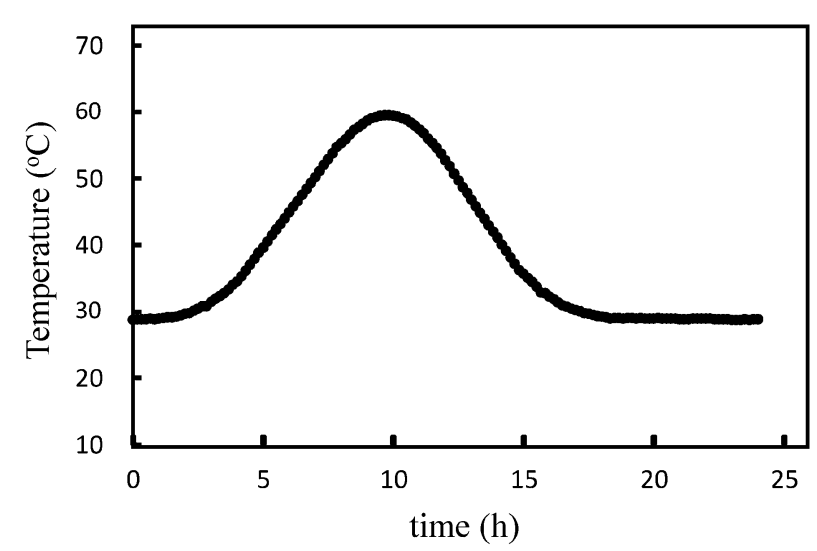

Fig. 1. The Time-course of the Model Ambient Temperature The maximum temperature was $59.5^{\circ} \mathrm{C}$. The minimum temperature was $28.7^{\circ} \mathrm{C}$. The mean kinetic temperature was $46^{\circ} \mathrm{C}$.
ODS 80 Ts $(4.6 \phi \times 150 \mathrm{~mm}$ TOSO $)$, カラム温度 : $50^{\circ} \mathrm{C}$, 溶出 : メ夕ノール $/ 0.02 \mathrm{M}$ リン酸緩衝液 $(\mathrm{pH}$ $3.0) / \mathrm{SDS}$ 混合溶液 $(620: 380: 5(\mathrm{~V} / \mathrm{V} / \mathrm{W}))$, 流 速 : $1.2 \mathrm{~mL} / \mathrm{min}$, 注入量 : $10 \mu \mathrm{L})$ により定量し た。測定は同一試料について 3 回繰り返した.

5. 活性化エネルギーと頻度因子 各等温環境 に保存した試料の活性成分濃度の時間変化を擬一次 反応速度式で解析して反応速度定数を求め，これを アレニウス式に当てはめて活性化エネルギーと頻度 因子を求めた。

6. 見かけの熱拡散率 試料 1 から 3 について 前報18) と同じ方法で見かけの熱拡散率を測定した。

7. 計算ソフト＼cjkstart計算は Excel 2003 （マイクロ ソフト社製）を用いた。

\section{結果 · 考察}

1. 活性化エネルギーＦigure 2 にVB1の残 存率の経時変化を示した。 今回試験したどの温度に おいても残存率の対数值と時間のプロットは良好な 直線関係を示し，VB1 の残存率の時間変化は擬一 次反応に従うと考えられた。 Table 2 に各温度での 擬一次反応速度定数 $\left(k_{o b s}\right)$ と決定係数 $\left(\mathrm{r}^{2}\right)$ を示 した. Figure 3 に各温度の擬一次反応速度定数のア レニウスプロットを示す。良好な直線関係 $\left(\mathrm{r}^{2}=\right.$ $0.998 ）$ が得られ，活性化エネルギーは $99.3 \mathrm{~kJ} /$ mol，頻度因子は $4.64 \times 10^{13}$ であった。

2. 試料温度の実測値と推定値各試料の見か けの熱拡散率 $\left(\kappa_{\mathrm{a}}\right)$ は，それぞれ，1.47 $\mathrm{h}^{-1}$ (試料 1), $0.414 \mathrm{~h}^{-1}$ (試料 2) 及び $0.145 \mathrm{~h}^{-1}$ （試料 3） で

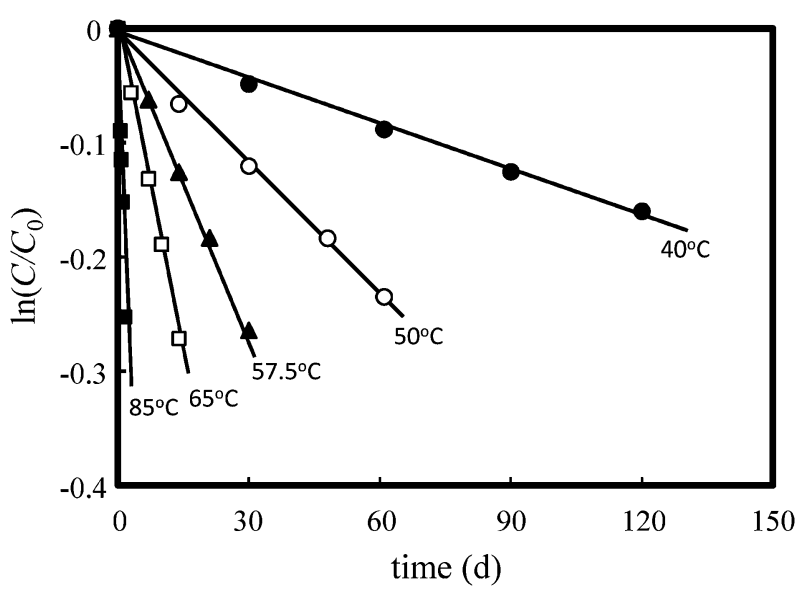

Fig. 2. Active Ingredient Residual Ratio $\left(\ln \left(C / C_{0}\right)\right)$ versus Time at Various Temperatures $\left(40,50,57.5,65\right.$ and $\left.85^{\circ} \mathrm{C}\right)$ 
Table 2. $k_{\text {obs }}$ Values at Various Temperatures

\begin{tabular}{ccc}
\hline \hline Temperature $\left({ }^{\circ} \mathrm{C}\right)$ & $k_{\text {obs }}\left(\mathrm{d}^{-1}\right)$ & $\mathrm{r}^{2}$ \\
\hline 85 & $1.57 \times 10^{-1}$ & 0.999 \\
65 & $1.93 \times 10^{-2}$ & 0.999 \\
57.5 & $8.78 \times 10^{-3}$ & 0.999 \\
50 & $3.76 \times 10^{-3}$ & 0.997 \\
40 & $1.32 \times 10^{-3}$ & 0.995
\end{tabular}

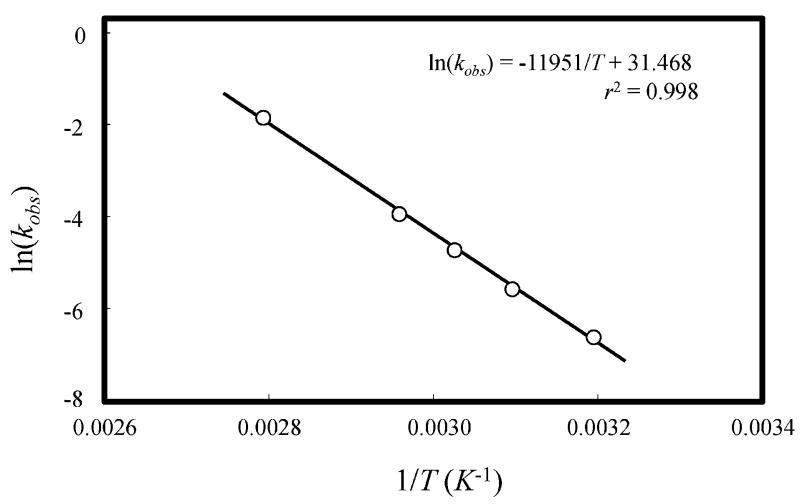

Fig. 3. Arrhenius Plot of the Pseudo-First-Order Reaction Rate Constant $\left(k_{o b s}\right)$
あった．前報18)で報告したように，試料 1 は見かけ の熱拡散率が大きい領域（ $1 \mathrm{~h}^{-1}$ 以上）に入り，試 料の温度が気温とほぼ同じになるため非等温環境で の平均反応速度を求めるに当たり熱伝導を考慮しな くてもよいと推定される.これに対し，試料 2 と 3 は見かけの熱拡散率の值が中間の領域に入るため, 試料温度は気温に追従しては変化せず，非等温環境 での平均反応速度を求めるに当たり熱伝導を考慮す る必要があると推定される. Figure 4 に試料 1 から 3 の試料温度の実測值と推定值及び気温を示した。 その結果, 試料温度の実測值と推定值はよく一致す ることが認められた。 また，試料 1 では試料温度と 気温がほぼ一致したが, 試料 2 と 3 では気温と試料 温度は一致せず，平均反応速度を求めるに当たり熱 伝導を考慮する必要があると考えられた。

3. 非等温環境での有効成分の安定性 モデル 非等温環境に保存した試料の VB1 残存率の経時変 化を Fig. 5 に示した。いずれの試料においても熱 伝導を考慮した平均反応速度定数から推定された VB1 の残存率は実測值とよく一致した。見かけの 熱拡散率が大きく試料温度が気温に追従する試料 1
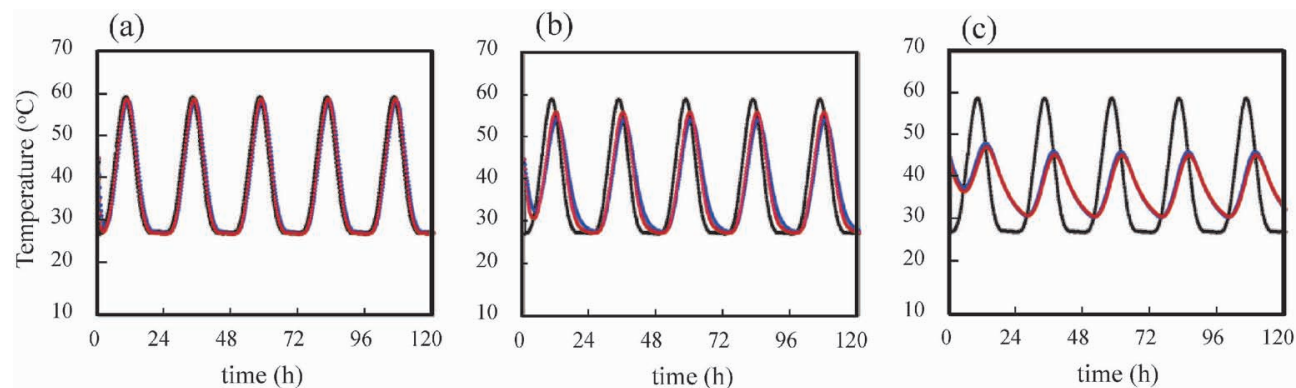

Fig. 4. The Time Courses for the Ambient Temperature, the Product Temperature, and the Estimated Temperatures of the Products The product initial temperature was the mean kinetic temperature of the ambient temperature. (a) Product 1, (b) product 2, (c) product 3. 0 : Ambient temperature, observed temperature of products, $\bigcirc$ : estimated temperature of products.

(a)

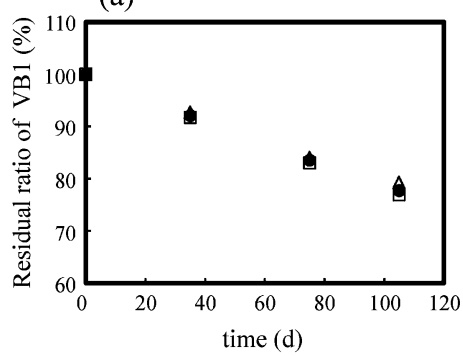

(b)

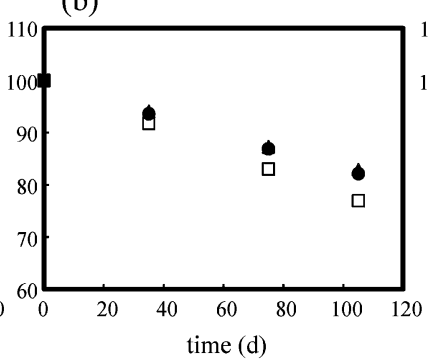

(c)

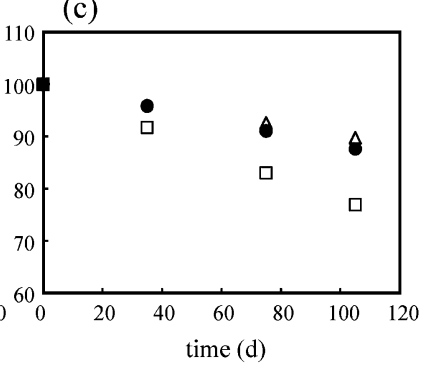

Fig. 5. The Time Courses for the Residual ratio of VB1 under Model Non-isothermal Condition

(a) Product 1, (b) product 2, (c) product 3. $\triangle$ : Observed data, : predicted data considering heat transfer, $\square$ : predicted data without considering heat transfer. 
においては熱伝導を考慮しない平均反応速度定数か ら推定されたVB1の残存率も実測值と一致してい る。しかし，見かけの熱拡散率が小さい試料 2 にお いては，熱伝導を考慮しない平均反応速度定数から 推定されたVB1 の残存率の予測值は実測值より小 さくなり，見かけの熱拡散率がさらに小さい試料 3 では，熱伝導を考慮しないとVB1 の残存率の予測 值と実測值の乘離がさらに大きくなった。これは, 見かけの熱拡散率が中間領域に入る試料 2 や 3 で は，熱伝導速度が有限の值をとるため，試料温度は 環境温度に完全には追従できず，試料温度の変動幅 が環境温度の変動幅より小さくなり，その結果，熱 伝導を考慮せずに算出した場合より実際の平均反応 速度が小さくなったと考えられる。したがって，前 報18)で報告したように見かけの熱拡散率が中間領域 ( $\kappa_{\mathrm{a}}$ が 0.001-1 $\left.\mathrm{h}^{-1}\right)$ に入る試料を非等温環境に保 存する場合には，活性成分の安定性を推定する上で 熱伝導を考慮する必要があると考えられる。一方, 見かけの熱拡散率が中間領域より小さく，かつ保存 開始時の製品温度と環境温度の差が小さい場合は, 容器の断熱性が高いため，製品の温度は実質上，保 存開始温度に保たれるので，活性成分の安定性は保 存開始温度で一定に保存された場合の分解速度から 推定すればよい.しかし，製品の保存開始温度と環 境温度の差が極端に大きい場合には，製品温度は環 境温度に向かつて徐々に変化するので，この製品温 度を Eq.（2）により算出し，この值を基に Eq. (3) から (5)を用いて活性成分の安定性を推定すればよ いと考えられる。この挙動は製品の見かけの熱拡散 率，保存開始時の製品温度と環境温度の差の大き さ，保存期間等により影響を受けるので，今後，定 量的な考察と検証が必要である。

\section{ま と め}

環境温度と製品温度の差による熱伝導を考慮し て，非等温環境に保存された製品に含まれる活性成 分の平均反応速度を算出し，その平均反応速度から 活性成分の化学的安定性を予測する方法を, VB1 を用いたモデル処方で検証した．その結果，実測值 と予測值はよく一致し，本方法は非等温環境下での 活性成分の化学的安定性を予測する方法として有用 であると考えられる。

\section{REFERENCES}

1) Rudland S. V., Jacobs A. G., BMJ, 308, 954956 (1994).

2) Allegra J. R., Brennan J., Lanier V., Lavery R., MacKenzie B., Acad. Emerg. Med., 6, 1098-1103 (1999).

3) Hogerzeil H. V., Battersby A., Srdanovic V., Stjernstrom N. E., BMJ, 304, 210-212 (1992) .

4) International Safe Transit Association, "Ocean Container Temperature and Humidity Study.": 〈http:// www.ista.org / forms / PST 2006Issue2.pdf $\rangle$, cited 21 February, 2013.

5) Grant T. A., Caroll R. G., Church W. H., Am. J. Emerg. Med., 12, 319-322 (1994).

6) Sanwa Paint Industry Company, Ltd.: 〈http:// www.sanwa-paint.co.jp/heatblock data.html, , cited 21 February, 2013.

7) Küpper T. E., Schraut B., Rieke B., Hemmerling A. V., Schöffl V., Steffgen J., J. Travel Med., 13, 35-47 (2006).

8) Haynes J. D., J. Pharm. Sci., 60, 927-929 (1971).

9) United States Pharmacopeia USP34/NF29: General information/ $\langle 1150\rangle$ " pharmaceutical stability," United States Pharmacopeial Convention, Rockville, 2011, pp. 693-694.

10) Kommanaboyina B., Rhodes C. T., Drug Dev. Ind. Pharm., 25, 1301-1306 (1999) .

11) Bott R. F., Oliveira W. P., Drug Dev. Ind. Pharm., 33, 393-401 (2007).

12) Zahn M., Kållberg P. W., Slappendel G. M., Smeenge H. M., J. Pharm. Sci., 95, 946-965 (2006) .

13) Carstensen J. T., Rhodes C. T., Drug Dev. Ind. Pharm., 12, 1219-1225 (1986).

14) Okusa N., Chem. Pharm. Bull., 23, 794-802 (1975).

15) Okusa N., Chem. Pharm. Bull., 23, 803-809 (1975).

16) Scher M., J. Pharm. Sci., 69, 325-327 (1980).

17) Terao M., Aoki K., Ueki Y., Chem. Pharm. Bull., 30, 2971-2979 (1982).

18) Nakamura T., Yamaji T., Takayama K., J. Pharm. Sci., 102, 1495-1503 (2013).

19) Laindler K. J., Pure Appl. Chem., 68, 149192 (1996). 